\title{
VJEŠTINE KAO KLJUČNI ČINITELJ ZAPOŠLJIVOSTI DIPLOMANATA POSLOVNE EKONOMIJE - PERCEPCIJE POSLODAVACA I DIPLOMANATA ${ }^{1}$
}

\author{
Izv. prof. dr. sc. Maja Klindžić \\ Ekonomski fakultet Zagreb \\ Trg J. F. Kennedyja 6, 10000 Zagreb, Republika Hrvatska \\ Telefon: 012383 264, e-mail: mklindzic@efzg.hr \\ Kristina Pavković, mag. oec. \\ Orbico d.o.o. \\ Ul. Kreše Golika 1, 10090, Zagreb, Republika Hrvatska \\ e-mail: kristina.pavkovic@orbico.com
}

\section{SAŽETAK}

Zapošljivost se odnosi na skup sposobnosti, znanja i vještina koje omogućavaju diplomantima da prošire mogućnosti za zapošljavanje i postignu daljnji napredak u svojoj karijeri. Glavni cilj rada bio je upravo ispitati koje su vještine ključne za diplomante poslovne ekonomije pri zapošljavanju te analizirati razliku u percepciji između poslodavaca i studenata s obzirom na razvijenost odabranih konceptualnih, socijalnih i tehničkih menadžerskih vještina. Provedeno je empirijsko istraživanje na uzorku 30 stručnjaka uglavnom iz područja upravljanja ljudskim potencijalima iz većinom velikih hrvatskih poduzeća, kao i na 100 nedavno diplomiranih magistara poslovne ekonomije s Ekonomskog fakulteta Sveučilišta u Zagrebu. Primarni podaci su prikupljeni anketnim upitnikom te analizirani primjenom metoda deskriptivne statistike. Rezultati istraživanja pokazali su da postoje značajne razlike u percepciji razvijenosti pojedinih menadžerskih vještina diplomanata. Diplomanti de facto precjenjuju gotovo sve vještine osim tehničkih znanja i vještina govorne komunikacije. Najveći jaz u procjeni identificiran je kod kritičke samosvijesti, rada u timu, upravljanje konfliktima i kritičkog mišljenja. Ovi rezultati mogu biti korisni sveučilištima kako bi ona mogla prilagoditi svoje studije na temelju zahtjeva tržišta rada, kao i studentima poslovne ekonomije koji mogu poboljšati svoj skup vještina i maksimizirati izglede za zapošljivost.

Ključne riječi: zapošljivost; diplomanti poslovne ekonomije; socijalne vještine; konceptualne vještine; tehničke vještine

1 Rad je djelomično nastao na temelju diplomskog rada kojeg je Kristina Pavković, mag. oec. napisala i obranila pod mentorstvom izv. prof. dr. sc. Maje Klindžić 


\section{UVOD}

Institucije visokog obrazovanja suočavaju se s pojačanim zahtjevima za odgovornošću, transparentnošću i usporedivošću, dijelom zbog vanjskih čimbenika (globalne konkurencije, promjene potreba klijenata), a dijelom i zbog unutarnjih čimbenika (npr. inicijative za uvođenjem sustava upravljanja kvalitetom ili želje za internacionalizacijom) (Azevedo, Apfelthaler i Hurst, 2012). Nakon uvođenja Bolonjske deklaracije, posebno su europska sveučilišta postala suočena sa zahtjevima da „proizvedu“ izrazito mobilne diplomante koji mogu odgovoriti na zahtjeve suvremenog radnog mjesta, koji se pak kontinuirano mijenjaju (Andrews i Higson, 2008).

U kontekstu prethodno spomenute mobilnosti, najčešće se istražuje zapošljivost diplomanata. Kao ključni faktor kojim se gradi zapošljivost u posljednjih su nekoliko godina identificirane različite menadžerske vještine koje mogu biti tehničkog, socijalnog ili konceptualnog karaktera (Katz, 1974; Horn, 2012). Ipak, od početka novog milenija, socijalne ili „meke“ vještine su se nametnule upravo kao „vještine 21 . stoljeća“ koje poslodavci u pravilu smatraju presudnima za uspjeh na radnom mjestu (npr. Alshare i Sewailem, 2018; Succi i Canovi, 2020). No, istraživanja generalno pokazuju da diplomanti koji prvi puta traže posao ne posjeduju osobne, transferabilne i vještine zapošljivosti koje poslodavci zahtijevaju odnosno žele (npr. Ananiadou i Claro, 2009; Davies, 2000; Lisa, Hennelova i Newman, 2019).

Diplomanti poslovne ekonomije obrazuju se u raznolikim područjima koja su potrebna bilo kojem sektoru odnosno djelatnosti. Drugim riječima, kvalitetan ekonomist potreban je i poduzetniku u odjelu prodaje ili odjelu za ljudske potencijale kao i javnoj zdravstvenoj ustanovi u odjelu za financije ili računovodstvo. No, diplomanti poslovne ekonomije se i objektivno i subjektivno percipiraju kao teže zapošljivi u odnosu na druge profesije (Mazalin i Parmač Kovačić, 2015). Naime, kako je ponuda ekonomista na tržištu rada doživjela proliferaciju u posljednjih nekoliko godina, a posebno uzevši u obzir pojačanu konkurenciju u vidu poslovnih škola kakvu ne poznaje niti jedno drugo područje visokog obrazovanja, od presudne je važnosti ponuditi poslodavcu konkurentna znanja odnosno vještine kako bi se maksimizirala vjerojatnost zapošljavanja i održavanja zapošljivosti. S obzirom da se pod zapošljivosti obično podrazumijeva „imovina“ diplomanata u smislu njihovih znanja, vještina i stavova koje posjeduju kao i načina na koji koriste tu imovinu (Lumley i Wilkinson, 2014), postavljena su dva istraživačka pitanja (IP) koja su potom istražena uz pomoć desk istraživanja i empirijskog istraživanja:

IP1: Koje vještine se smatraju ključnima za zapošljivost diplomanata poslovne ekonomije?

IP2: U kojoj mjeri su vještine važne za zapošljivost zaista razvijene kod diplomanata poslovne ekonomije te postoji li jaz između diplomanata i poslodavaca u procjeni razvijenosti pojedinih vještina važnih za zapošljivost? 


\section{ODREĐENJE KONCEPTA ZAPOŠLJIVOSTI I POVEZANIH VJEŠTINA DIPLOMANATA}

Premda univerzalno prihvaćen i popularan pojam, zapošljivost (engl. Employability) je kompleksan a pomalo i nejasan koncept kojeg je teško artikulirati i definirati (Andrews i Higson, 2008). Ipak, pod njime se najčešće podrazumijeva pojedinčeva sposobnost dobivanja prvog posla (Lisa et al., 2019), zadržavanja posla te ako je potrebno, pronalaska novog posla (Lumley i Wilkinson, 2014). Njime se, dakle, promiče suvremena alternativa sigurnosti posla (Maslić Seršić i Tomas, 2015) koja unatrag posljednjih nekoliko desetljeća, uslijed globalizacije i izrazite promjenjivosti okoline, postaje i svojevrsni standard na tržištu rada. Područje zapošljivosti istražuju stručnjaci u području strukovnog obrazovanja i obrazovanja odraslih, karijerni savjetnici te akademici (Lumley i Wilkinson, 2014), a interes se širi na sferu cjelokupnog društva. Štoviše, mnoge su ekonomije od 1980-ih godina prigrlile koncept spremnosti diplomanata za tržište rada odnosno njihovu zapošljivost kao sredstvo promocije nacionalne konkurentnosti u globalnom okruženju (Azevedo et al., 2012). Naime, anticipiranje i stjecanje vještina za budućnost je ključno na tržištu rada koje se izrazito brzo mijenja jer nedostatak vještina može rezultirati nepovoljnim socio-ekonomskim posljedicama na ekonomske indikatore poput razvoja i zaposlenosti (ILO, 2017).

Dimenzije zapošljivosti definiraju se prema stranama tržišta rada - ponude i potražnje, pri čemu se posljednjih nekoliko godina veća pažnja pridaje strani potražnje odnosno ljudskom kapitalu i njegovim karakteristikama (Mazalin i Parmač Kovačić, 2015). Za pojedince, zapošljivost će stoga ovisiti o nekoliko faktora među kojima su njihova imovina u smislu znanja, vještina i stavova koje posjeduju; način na koji koriste tu imovinu; način na koji se predstavljaju poslodavcu; i, ključno, kontekst unutar kojeg se nalazi posao (primjerice, osobne okolnosti i stanje na tržištu rada) (Lumley i Wilkinson, 2014).

„Koje su vještine ključne za studente poslovne ekonomije kako bi oni bili uspješni u poslu?" često je pitanje koje se pojavljuje na fakultetskim sastancima, konferencijama i skupovima na kojima su tema kurikulumi sveučilišta (Jance i Morgan, 2013), a pri tome je jedan skup vještina uvijek u samom središtu rasprava o zapošljivosti - takozvane „meke vještine“ (Hora, Benbow i Smolarek, 2018; Succi i Canovi, 2020). Generalno govoreći, zapošljivost se često promatra kroz prizmu skupa vještina koje osiguravaju povoljan položaj na tržištu rada te se one tipično dijele na tri grupe. Riječ je o generičkim vještinama (rada u timu ili komunikacijskih vještina); vještinama specifičnima za profesiju (vještine inženjerstva, prava, socijalnog rada); te osobnim atributima (samopouzdanje, ustrajanje u nepovoljnim okolnostima, lojalnost, integritet) (Lisa et al., 2019).

Vrlo slično, u kontekstu menadžerskih vještina generalno se mogu razlikovati tri skupa vještina - konceptualne, tehničke i socijalne vještine (Katz, 1974). Pri tome se tehničke vještine odnose na stručna znanja koje studenti odnosno diplomanti stječu u području u kojem su se odlučili specijalizirati (primjerice, znanja knjiženja u računovodstvu ili programiranja u računarstvu). Konceptualne vještine su pak vrlo sofisticirane vještine koje se povezuju sa sposobnošću sagledavanja „šire“ slike, rješavanja složenih problema odnosno razumijevanja odnosa dijelova i cjeline (Horn, 2012). Konačno, socijalne vještine podrazumijevaju širok dijapazon vještina poput interpersonalnih, komunikacijskih, prezentacijskih, pregovaračkih vještina, rada u timu, upravljanja sukobima, upravljanja različitostima 
i dr. Ova posljednja grupa vještina omogućuju uspješnu suradnju u studentskim ili radnim kolektivima.

Često se u kontekstu zapošljivosti o socijalnim, a djelomično i i konceptualnim vještinama govori kao o „vještinama 21. stoljeća“ (npr. Trilling i Fadel, 2009) kojima poslodavci teže, a na koje se obrazovne institucije trebaju fokusirati u svojim kurikulumima (npr. Alshare i Sewailem, 2018; Ananiadou i Claro, 2009; Hodge i Lear, 2011; Lisa et al., 2019; Roterham i Willingham, 2010; Silva, 2009; Trilling i Fadel, 2009). To su upravo socijalne, stavovne i samoregulacijske kompetencije ili osobine koje pojedincima omogućuju učinkovitu komunikaciju, dobar rad s drugima i ustrajanje uslijed nepovoljnih okolnosti (Hora et al., 2018).

\section{EMPIRIJSKO ISTRAŽIVANJE O PERCEPCIJI RAZVIJENOSTI VJEŠTINA DIPLOMANATA POSLOVNE EKONOMIJE}

\subsection{Metodologija istraživanja}

Instrument istraživanja bio je anketni upitnik, pri čemu je kreiran zasebni upitnik za uzorak poslodavaca te zasebni upitnik za uzorak diplomanata. Oba upitnika su sadržavala ključno pitanje u kojem su diplomanti trebali dati samoprocjenu razvijenosti odabranih vještina uz pomoć skale Likertovog tipa od 5 stupnjeva ( 1 - vještina je potpuno nerazvijena, 5 - vještina je u potpunosti razvijena), dok su poslodavci procjenjivali mjeru do koje su vještine razvijene kod diplomanata poslovne ekonomije zaposlenih u njihovim poduzećima. Popis vještina identificiran je putem analize sekundarnih izvora (npr. Alshare i Sewailem, 2018; Succi i Canovi, 2020; Hodge i Lear, 2011; Lisa et al., 2019; Roterham i Willingham, 2010). Oba upitnika sadržavala su i nekoliko dodatnih pitanja o socio-demografskim karakteristikama ispitanika i poslodavaca.

Prikupljanje i obrada podataka. Ispitivanje se provodilo elektronskim putem pri čemu je anketni upitnik poslodavcima distribuiran putem elektronske pošte, a diplomantima putem elektronske pošte, društvenih mreža te odabrane komunikacijske platforme. Anketiranje se provodilo od druge polovice srpnja do početka rujna 2019. godine. Za obradu podataka se koristio program IBM SPSS Statistics 26.0. Metode statističke analize korištene za obradu prikupljenih podataka su deskriptivnog tipa.

Istraživački uzorak. Anketni upitnik za poslodavce distribuiran je u srpnju 2019. godine na približno 50 adresa elektroničke pošte potencijalnih sudionika u segmentu poslodavaca koji su mahom pripadali srednjim i velikim poslodavcima. Ispitanici su trebali imati kontakt s diplomantima poslovne ekonomije na razini stručnog ili sveučilišnog studija (prilikom zapošljavanja, proučavanja životopisa, daljnjeg rada s njima, mentoriranja na poslu i sl.). Anketni upitnici u segmentu diplomanata su uglavnom prikupljeni koristeći mreže poznanstava. Sredinom rujna 2019. godine zaključena je faza prikupljanja anketnih upitnika kada je prikupljeno 30 odgovora poslodavaca te 100 odgovora diplomanata poslovne ekonomije. Karakteristike obje grupe ispitanika su prikazane u tablici 1. 
Tablica 1. Socio-demografske karakteristike poslodavaca i diplomanata u uzorku

\begin{tabular}{|c|c|c|c|}
\hline \multicolumn{2}{|r|}{ Nezavisne karakteristike poslodavaca $(\mathrm{N}=30)$} & f & $\%$ \\
\hline \multirow{3}{*}{$\begin{array}{l}\text { Uloga u } \\
\text { organizaciji }\end{array}$} & Menadžer ili specijalist u odjelu za ljudske potencijale (LJP) & 14 & $46,7 \%$ \\
\hline & $\begin{array}{l}\text { Menadžer funkcijskog odjela u kojem rade diplomanti poslovne } \\
\text { ekonomije }\end{array}$ & 11 & $36,7 \%$ \\
\hline & Suradnik diplomanata poslovne ekonomije & 5 & $16,7 \%$ \\
\hline \multirow{2}{*}{$\begin{array}{l}\text { Veličina } \\
\text { organizacije }\end{array}$} & Malo ili srednje poduzeće & 6 & $20 \%$ \\
\hline & Veliko poduzeće & 24 & $80 \%$ \\
\hline \multicolumn{2}{|r|}{ Nezavisne karakteristike diplomanata $(\mathrm{N}=100)$} & f & $\%$ \\
\hline \multirow[b]{2}{*}{ Spol } & Ženski & 82 & $82 \%$ \\
\hline & Muški & 18 & $18 \%$ \\
\hline \multirow{3}{*}{ Dob } & $<23$ & 13 & $13 \%$ \\
\hline & $24-28$ & 82 & $82 \%$ \\
\hline & $>29$ & 5 & $5 \%$ \\
\hline \multirow{3}{*}{$\begin{array}{l}\text { Sveučilišni } \\
\text { studij }\end{array}$} & Stručni preddiplomski ili diplomski studij & 29 & $29 \%$ \\
\hline & Diplomski sveučilišni studij & 58 & $58 \%$ \\
\hline & Poslijediplomski studij & 13 & $13 \%$ \\
\hline \multirow{5}{*}{ Radni status } & Zaposlen/a - ugovor na neodređeno vrijeme & 29 & $29 \%$ \\
\hline & Zaposlen/a - ugovor na određeno vrijeme & 16 & $16 \%$ \\
\hline & Pripravnik & 12 & $12 \%$ \\
\hline & Ostale vrste radnog odnosa & 9 & $9 \%$ \\
\hline & Nezaposlen/a & 34 & $34 \%$ \\
\hline
\end{tabular}

U segmentu poslodavaca, prisutna je gotovo polovica menadžera ili specijalista u odjelima za LJP, dok je trećina na čelu odjela u kojem je najviše zaposlenih upravo diplomanata poslovne ekonomije. Najveći broj poslodavaca dolazi iz skupine velikih poduzeća odnosno onih koji zapošljavaju više od 250 zaposlenika, dok je malih i srednjih poslodavaca prisutan jednak broj, a sveukupno $20 \%$. U segmentu diplomanata najviše je žena te ispitanika koji imaju između 24 i 28 godina, pri čemu dvije trećine ima završen diplomski studij, a u trenutku provedbe istraživanja dvije trećine ispitanika je bilo u nekom obliku radnog odnosa.

\subsection{Rezultati istraživanja}

Razvijenost vještina diplomanata poslovne ekonomije. Glavni cilj istraživanja bio je ispitati percepcije poslodavaca i diplomanata o razvijenosti pojedinih menadžerskih vještina koje su u dostupnoj literaturi identificirane kao posebno važne za zapošljivost diplomanata poslovne ekonomije. Komparativna deskriptivna analiza stavova obje skupine ispitanika prikazana je uz pomoć pokazatelja aritmetičke sredine (AS), moda (Mo), medijana (Med) i standardne devijacije (SD) te razlike aritmetičkih sredina oba uzorka za svaku vještinu $(\Delta)$, što je prikazano u tablici 2. 
Prema podacima iz tablice 2 vidljivo je da diplomanti poslovne ekonomije veći dio menadžerskih vještina u vlastitu slučaju percipiraju kao iznadprosječno razvijene (AS> 3.5), pri čemu se posebno izdvajaju socijalne vještine i to: vještine rada u timu $(A S=4.18$, $\mathrm{Mo}=5)$, pisana komunikacija ( $\mathrm{AS}=4.04, \mathrm{Mo}=5)$, kao i vještine rada u raznolikom okruženju ( $A S=4.01, M o=4)$. Diplomanti istovremeno smatraju da su im najmanje razvijene tehničke vještine odnosno primjena naučenog u praksi (AS=3.39, Mo=3) te analiza kvantitativnih podataka ( $\mathrm{AS}=3.46, \mathrm{Mo}=4)$, kao i konceptualna vještina kreativnosti (AS=3.42, Mo=4). Ipak, i ove se vještine, prema samoprocjeni studenata odnosno iz njihove perspektive, mogu smatrati barem prosječno razvijenima.

Istovremeno, postoje prilično velike razlike u odnosu na poslodavce tj. njihovu percepciju razvijenosti pojedinih vještina kod diplomanata poslovne ekonomije pri čemu se poslodavci bili puno kritičniji. Kao najrazvijenije vještine poslodavci, u prosjeku, smatraju vještine korištenja informacijske tehnologije $(\mathrm{AS}=4.03, \mathrm{Mo}=4)$ i verbalnu komunikaciju $(A S=3.83, M o=4)$. To su ujedno i jedine dvije vještine koje su poslodavci ocijenili povoljnije u odnosu na diplomante - drugim riječima, potonji su se u ova dva područja podcijenili. No, zabrinjava činjenica da postoji velik broj područja u kojima su se diplomanti precijenili i to za polovicu ili čak cijelu ocjenu. Najveći jaz u percepciji razvijenosti vještina je u područjima: kritičke samosvijesti ( $\Delta=1.14$; Mo=2), upravljanja sukobima $(\Delta=0.61, \mathrm{Mo}=3)$, neovisnosti gledišta $(\Delta=0.60, \mathrm{Mo}=3)$, upravljanja vremenom $(\Delta=0.45, \mathrm{Mo}=3)$ i rada u timu $(\Delta=0.43, \mathrm{Mo}=4)$. 
Tablica 2. Komparativna analiza percepcije diplomanata i poslodavaca o razvijenosti vještina diplomanata poslovne ekonomije

\begin{tabular}{|c|c|c|c|c|c|c|c|c|c|c|}
\hline \multirow{2}{*}{\multicolumn{2}{|c|}{ Odabrane menadžerske vještine }} & \multicolumn{4}{|c|}{ Diplomanti (D) } & \multicolumn{4}{|c|}{ Poslodavci (P) } & \multirow{3}{*}{$\begin{array}{c}\text { Razlike } \\
\text { AS (D - P) } \\
0.14\end{array}$} \\
\hline & & \multirow{2}{*}{$\begin{array}{l}\text { AS } \\
3.67\end{array}$} & \multirow{2}{*}{$\begin{array}{c}\text { Mod } \\
4\end{array}$} & \multirow{2}{*}{$\begin{array}{c}\text { Med } \\
4\end{array}$} & \multirow{2}{*}{$\begin{array}{c}\text { SD } \\
1.01\end{array}$} & \multirow{2}{*}{$\begin{array}{c}\text { AS } \\
3.53\end{array}$} & \multirow{2}{*}{$\begin{array}{c}\text { Mod } \\
4\end{array}$} & \multirow{2}{*}{$\begin{array}{c}\text { Med } \\
4\end{array}$} & \multirow{2}{*}{$\begin{array}{c}\text { SD } \\
0.81\end{array}$} & \\
\hline$\stackrel{0}{E}$ & $\begin{array}{l}\text { Prilagodljivost novonastalim } \\
\text { situacijama }\end{array}$ & & & & & & & & & \\
\hline$\cdot \frac{0}{2}$ & Kreativnost & 3.42 & 4 & 4 & 1.11 & 3.23 & 4 & 3 & 1.16 & 0.19 \\
\hline$\underset{\frac{c}{0}}{\frac{0}{\partial}}$ & $\begin{array}{l}\text { Vještine rješavanja } \\
\text { problema }\end{array}$ & 3.57 & 4 & 4 & 1.04 & 3.34 & 4 & 4 & 1.11 & 0.23 \\
\hline$\stackrel{\mathscr{U}}{\subseteq}$ & Neovisnost gledišta & 3.66 & 4 & 4 & 1.10 & 3.06 & 3 & 3 & 1.13 & 0.60 \\
\hline & Upravljanje vremenom & 3.71 & 4 & 4 & 0.97 & 3.26 & 4 & 4 & 1.04 & 0.45 \\
\hline \multirow{7}{*}{ 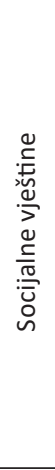 } & Kritička samosvijest & 3.77 & 4 & 4 & 1.16 & 2.63 & 2 & 2 & 1.12 & 1.14 \\
\hline & Rad u timu & 4.18 & 5 & 4 & 0.97 & 3.75 & 4 & 4 & 0.95 & 0.43 \\
\hline & $\begin{array}{l}\text { Sposobnost jasnog } \\
\text { komuniciranja u govoru }\end{array}$ & 3.78 & 4 & 4 & 1.04 & 3.83 & 4 & 4 & 0.98 & -0.05 \\
\hline & $\begin{array}{l}\text { Sposobnost jasnog } \\
\text { komuniciranja u pisanom } \\
\text { obliku }\end{array}$ & 4.04 & 5 & 4 & 1.00 & 3.66 & 4 & 4 & 0.95 & 0.38 \\
\hline & Upravljanje sukobima & 3.67 & 4 & 4 & 1.10 & 3.06 & 3 & 3 & 0.96 & 0.61 \\
\hline & Pregovaranje & 3.51 & 4 & 4 & 1.13 & 3.21 & 3 & 3 & 1.03 & 0.30 \\
\hline & $\begin{array}{l}\text { Rad u raznolikom radnom } \\
\text { okruženju }\end{array}$ & 4.01 & 4 & 4 & 0.95 & 3.63 & 4 & 4 & 1.15 & 0.38 \\
\hline \multirow{3}{*}{ 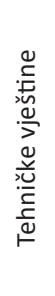 } & $\begin{array}{l}\text { Sposobnost analize i } \\
\text { interpretacije kvantitativnih } \\
\text { podataka }\end{array}$ & 3.46 & 4 & 4 & 0.95 & 3.36 & 4 & 4 & 1.21 & 0.10 \\
\hline & $\begin{array}{l}\text { Vještine korištenja } \\
\text { informatičke tehnologije }\end{array}$ & 3.68 & 4 & 4 & 1.04 & 4.03 & 4 & 4 & 0.76 & -0.35 \\
\hline & $\begin{array}{l}\text { Sposobnost primjene onoga } \\
\text { što je naučeno u širem } \\
\text { smislu }\end{array}$ & 3.39 & 3 & 3 & 1.06 & 3.30 & 3 & 3 & 1.05 & 0.09 \\
\hline
\end{tabular}

\section{RASPRAVA}

Prema rezultatima istraživanja, čini se da hrvatski poslodavci najrazvijenijima ocjenjuju tehničke vještine diplomanata poslovne ekonomije. Istovremeno, ova studija je pokazala kako je mišljenje hrvatskih poslodavaca da diplomantima izrazito nedostaju socijalne vještine koje se odnose na emocionalnu inteligenciju u smislu poznavanja vlastitih snaga i slabosti što je vidljivo iz nisko ocijenjene kritičke samosvijesti te interpersonalne vještine rada u timovima i efikasnog rješavanja sukoba. Osim toga, čini se da su i određene konceptualne vještine, prema mišljenju poslodavaca, nedovoljno razvijene, a one se pak odnose na upravljanje vremenom i kritičko razmišljanje. Diplomanti se pak u velikom broju vještina značajno precjenjuju, međutim, druga istraživanja ovog tipa pokazuju vrlo sličnu ten- 
denciju - u odnosu na samoprocjenu diplomanata, menadžeri iste vještine često ocjenjuju puno manje razvijenima (Lisa et al., 2019).

Trenutna studija de facto potvrđuje stavove poslodavaca diljem svijeta, a to je da oni generalno nisu zadovoljni stupnjem razvoja pojedinih vještina diplomanata poslovne ekonomije. Istovremeno, u istraživanjima u kojima se kompariraju stavovi diplomanata i poslodavaca, pokazuje se da diplomanti često identificiraju "tvrde" vještine kao važne komponente njihova vlastita portfolija vještina (Ananiadou i Claro, 2009; Lisa et al., 2019), ali da im „meke“ vještine poput onih komunikacijskih ili prezentacijskih nedostaju pri čemu prijavljuju da ih nisu niti imali prilike razvijati za vrijeme studiranja (npr. Ananiadou i Claro, 2009). Također, čini se i da poslodavci procjenjuju upravo tehničke vještine, poput IT vještina i traganja za informacijama kao, u pravilu, razvijene kod studenata poslovne ekonomije (Alshare i Sewailem, 2018; Andrews i Higson, 2008; Jance i Morgan, 2013).

S obzirom na Katzovu (1974) klasifikaciju vještina, smatra se da su socijalne vještine vještine 21. stoljeća, a opet, važan dio ovog skupa vještina, poput prilagodljivosti, komunikacije te interpersonalnih vještina, nedovoljno je razvijen kod diplomanata poslovne ekonomije (npr. Alshare i Sewailem, 2018; Hodge i Lear, 2011). Današnji poslodavci od novih zaposlenika, odnosno pripravnika očekuju da su interpersonalne vještine po završetku studija već razvijene (Bedwell et al., 2014), posebno zbog činjenice da se posao od početka sve više temelji na grupnom radu, stoga očekuju od diplomanata da budu sposobni raditi s drugima, da stvaraju senzibilitet prema suradnicima te da poštuju tuđe ideje i misli (Ritter et al., 2018).

Također, vrlo često se spominje vještina upravljanja samim sobom kao vještina od presudne važnosti za efikasan rad u poslovnom okruženju (Davies, 2000; Freunderberg et al., 2011; Andrews i Higson, 2008). Ipak, upravo je ovo vještina za koju se pokazao najveći jaz u percepciji njezine razvijenosti. Također, prema mišljenju poslodavaca, upravljanje samim sobom je najmanje razvijena vještina diplomanata poslovne ekonomije, a implikacije njezina deficita su ozbiljne jer je kritička samosvijest jedna od dimenzija emocionalne inteligencije koja je pak temelj za izgradnju interpersonalnih odnosa (npr. Goleman, 2010). Samosvijest se odnosi na prepoznavanje i razumijevanje vlastitih emocija, raspoloženja i ponašanja te kako ona utječu na druge ljude. Osobe koje imaju razvijenu samosvijest su samopouzdane osobe koje rado primaju povratnu informaciju pa čak i onu negativnu jer shvaćaju da je to prilika za učenje; odgovorne su i realne u samoprocjeni vlastitih snaga i slabosti (Goleman, 2010). No, nije neobično da se diplomanti značajno precjenjuju na ovoj dimenziji emocionalne inteligencije - naime, longitudinalno istraživanje provedeno u SAD-u je pokazalo da, iako 95\% ljudi smatra da ima razvijenu samosvijest, svega njih $10-15 \%$ zaista i jest kritički samosvjesno (Eurich, 2018).

Implikacije za diplomante, poslodavce i sveučilišta. Zapošljavanje diplomanata sve više postaje „valuta modernog doba“, odnosno ključno mjerilo vrijednosti fakulteta i sveučilišta. Fakulteti sve češće mjere brzinu zapošljivosti studenata nakon diplome, kao i profil poslodavaca koji zapošljavaju diplomante te njihovo zadovoljstvo diplomantima. Primjećuje se kako poslodavci u studijama provedenima u vrlo različitim zemljama kao problem gotovo konzistentno navode "meke“ vještine (Silva, 2009), što ukazuje na problem, jer poslodavci „najčešće nemaju vremena i sredstava poboljšavati „meke“ vještine diplomanata" (Bedwell et al., 2014). 
Čini se kako su studijski programi i očekivanja poslodavaca u većoj mjeri neusklađeni, barem kada je razvoj specifičnih vještina u pitanju. Hora i sur. (2018) vrlo kritično krivnju prebacuju gotovo ekskluzivno na sveučilišta te tvrde da, premda sve veći broj fakulteta u svoje kurikulume zaista integrira „meke“ vještine, ona to rade samo deklarativno jer u stvarnosti zanemaruju stručnost nastavnika potrebnu za pravilno usađivanje tih vještina studentima. Poslodavci stoga sve više izražavaju brigu oko uspjeha ishoda učenja u obrazovanju iz poslovne ekonomije, a jaz između onoga što poduzetnici-poslodavci žele i koje atribute diplomanti zaista posjeduju se ponekad širi čak i na generičke vještine (Freunderberg et al., 2011). Opravdano se postavlja pitanje što sveučilišta mogu učiniti da diplomantima povećaju zapošljivost na tržištu rada. Ono što je sigurno je da poduzetnici trebaju raditi u partnerstvu sa sveučilištima. Od poslodavaca su potrebni snažniji i dosljedniji signali da su im, primjerice, određene „meke“ vještine važnije od nekih drugih vještina. Zanimljivo je kako Andrews i Higson (2008) zagovaraju da te poruke budu dostupne još u „pretpristupnom“ razdoblju za sveučilište, kako bi roditelji i studenti mogli biti bolje informirani o zahtjevima poduzeća za zapošljivošću.

Što se tiče fakulteta, studijske programe na polju poslovne ekonomije treba aktualizirati, u većoj mjeri primjenjivati nove nastavne metode i druge inovacije u nastavnom procesu, međusobno povezivati nastavne sadržaje različitih kolegija i dinamizirati proces izmjena sadržaja studijskih programa (Krajnović, Vrdoljak Raguž i Bosna, 2019). Vezano uz prethodnu preporuku, poslodavci obično od sveučilišta očekuju uvođenje raznolikijih nastavnih metoda, kao što su praktične studije slučaja, grupne diskusije, prezentacije poslovnih izvještaja i izvještaja za klijente te studentske prakse (Lisa et al., 2019). Ako, primjerice, poslodavci konzistentno šalju poruke da su im potrebni ekonomisti s razvijenim vještinama timskog rada, onda sveučilišta mogu dodatno razmotriti gdje se u kurikulum mogu integrirati upravo te vještine (Andrews i Higson, 2008).

I studenti, odnosno diplomanti trebaju preuzeti odgovornost (Succi i Canovi, 2020) te aktivno raditi na relevantnim aspektima svoje osobnosti kroz formalno, neformalno i informalno obrazovanje (Jackson \& Bridgstock, 2021), rad i društvena iskustva koja unaprjeđuju transfer vještina (Jackson, 2014). To je moguće učiniti na više načina, a osim onih na individualnoj razini koje može poduzeti svaki pojedinac samostalno, fakulteti također mogu pomoći kroz centre karijere. Sveukupno, prijedlozi i preporuke se mogu sumirati na razini pojedinca (diplomanata/studenata) i organizacije (sveučilišta) i to za vještine za koje se pokazao najveći jaz u percepciji poslodavaca i diplomanata o njihovoj razvijenosti. Te preporuke su prikazane u tablici 4.

Ograničenja istraživanja i preporuke za buduća istraživanja. Ograničenja trenutnog istraživanja ogledaju se u činjenici da je kvantitativno istraživanje provedeno na dva krossekcijska uzorka koja su prigodnog karaktera. Također, uzorak diplomanata je ograničen na one koji su završili Ekonomski fakultet Sveučilišta u Zagrebu. Dodatno, s obzirom da je instrument istraživanja bio anketni upitnik, nije bilo moguće dobiti bogatije podatke osim kvantitativnih procjena putem skala Likertovog tipa. Buduća istraživanja bi svakako mogla, osim pokušaja da se obuhvati veći dio populacije poslodavaca, ali i studenata poslovne ekonomije iz svih dijelova Hrvatske, upotrijebiti kvalitativnu metodologiju kojom bi se moglo doći do detaljnijih uvida u to što poslodavci zaista očekuju od diplomanata te koje probleme vide u razvoju njihovih vještina tijekom studija. 
Tablica 4. Prijedlozi i preporuke za unaprjeđenje vještina diplomanata poslovne ekonomije na individualnoj i organizacijskoj razini

\begin{tabular}{|c|c|c|}
\hline & Diplomanti & Fakulteti i sveučilišta \\
\hline 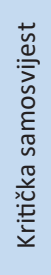 & $\begin{array}{l}\text { - Traženje povratne informacije od prijatelja, } \\
\text { kolega ili suradnika o vlastitom ponašanju } \\
\text { - Samoedukacija putem čitanja o načinima } \\
\text { unaprjeđenja samosvijesti } \\
\text { - Autorefleksija, mindfulness tehnike i } \\
\text { meditacija } \\
\text { - Zapisivanje dnevnika misli i ponašanja }\end{array}$ & $\begin{array}{l}\text { - Radionice u okviru centra za karijere o } \\
\text { emocionalnoj inteligenciji } \\
\text { - Provođenje procjena u okviru centra } \\
\text { za karijere putem (ne)standardnih } \\
\text { instrumenata procjene } \\
\text { - Samoocjenjivanje studenata u okviru } \\
\text { nastave i pružanje povratne informacije od } \\
\text { kolega i nastavnika }\end{array}$ \\
\hline 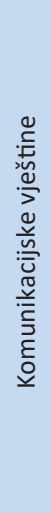 & $\begin{array}{l}\text { - Češće uključivanje u diskusije i rasprave za } \\
\text { vrijeme nastave } \\
\text { - Češće uključivanje u javne nastupe na } \\
\text { fakultetu u okviru redovite nastave ili rada u } \\
\text { studentskim udrugama } \\
\text { - Čitanje o praksama i karakteristikama } \\
\text { velikih govornika } \\
\text { - Proučavanje literature i video zapisa o } \\
\text { značenju neverbalnih znakova komunikacije } \\
\text { ili nošenju sa strahom od javnog govora } \\
\text { - Češće sudjelovanje u pisanim zadacima i } \\
\text { esejima u okviru nastave ili studentskih } \\
\text { časopisa } \\
\text { - Traženje povratne informacije od profesora } \\
\text { o pisanoj komunikaciji (eseju) }\end{array}$ & $\begin{array}{l}\text { - Radionice u okviru centra za karijere o } \\
\text { pisanju životopisa i motivacijskih pisama } \\
\text { te ponašanju na selekcijskim intervjuima ili } \\
\text { javnim nastupima } \\
\text { - Radionice o akademskom pisanju u okviru } \\
\text { redovite nastave ili kao zasebni događaji u } \\
\text { centru za karijere } \\
\text { - Uključivanje javnih nastupa kroz izlaganje } \\
\text { unaprijed pripremljenog sadržaja u } \\
\text { kurikulume kolegija } \\
\text { - U suradnji s poslodavcima, organiziranje } \\
\text { događanja poput sajma karijera i Business } \\
\text { Match Making-a, na kojima studenti } \\
\text { mogu postavljati pitanja potencijalnim } \\
\text { poslodavcima }\end{array}$ \\
\hline 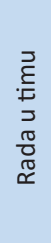 & $\begin{array}{l}\text { - Rad u studentskim udrugama koje su često } \\
\text { organizirane timski } \\
\text { - Proučavanje literature o grupnoj dinamici } \\
\text { i faktorima koji utječu na uspješnost rada } \\
\text { u timu } \\
\text { - Samoprocjena primarne grupne uloge } \\
\text { putem javnog dostupnih instrumenta }\end{array}$ & $\begin{array}{l}\text { - Uvođenje grupnog rada kao standardni oblik } \\
\text { rada studenata na seminarskoj nastavi } \\
\text { - Izvođenje eksperimenata na kolegijima } \\
\text { u području menadžmenta kojima bi se } \\
\text { pojasnile posebnosti grupne dinamike }\end{array}$ \\
\hline 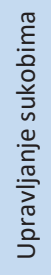 & $\begin{array}{l}\text { - Razvoj kritičke samosvijesti - poznavanje } \\
\text { vlastitih snaga i slabosti odnosno prednosti i } \\
\text { nedostataka u smislu karakteristika ličnosti } \\
\text { te kako naše reakcije potencijalno mogu } \\
\text { utjecati na druge ljude } \\
\text { - Čitanje literature o razvoju samokontrole u } \\
\text { cilju pragmatičnijih reakcija i boljeg izbora } \\
\text { stila upravljanja sukobima ovisno o situaciji }\end{array}$ & $\begin{array}{l}\text { - U okviru kolegija koji se dotiču vještina } \\
\text { pregovaranja i prodaje, uvođenje } \\
\text { suvremenih nastavnih metoda poput igranja } \\
\text { uloga u stvarnim poslovnim situacijama, } \\
\text { primjerice, razgovora s nezadovoljnim } \\
\text { klijentom ili suradnikom } \\
\text { - U okviru centra za karijere organizirati } \\
\text { radionice o upravljanju sukobima }\end{array}$ \\
\hline 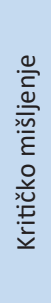 & $\begin{array}{l}\text { - Razvoj kritičke samosvijesti odnosno } \\
\text { osvještavanje onoga što znamo i što ne } \\
\text { znamo o području specijalizacije } \\
\text { - Svaki problem ili pitanje pokušati sagledati } \\
\text { iz svih kutova odnosno pronaći sve dobre } \\
\text { i loše strane, prednosti i nedostatke, } \\
\text { argumente i protuargumente }\end{array}$ & $\begin{array}{l}\text { - Poticanje studenata na preuzimanje } \\
\text { inicijative pri izlaganju vlastitog mišljenja } \\
\text { tijekom nastavnog procesa } \\
\text { - Korištenje debata i diskusija kao nastavne } \\
\text { metode } \\
\text { - Uključivanje studija slučaja potencijalnih } \\
\text { poslodavaca u nastavni proces te poticanje } \\
\text { studenata na međusobno propitkivanje } \\
\text { pojedinih rješenja }\end{array}$ \\
\hline
\end{tabular}




\begin{tabular}{|c|c|c|}
\hline 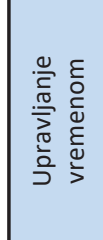 & $\begin{array}{l}\text { - Proučavanje literature i videozapisa o } \\
\text { tehnikama i alatima upravljanja vremenom } \\
\text { - Rad u studentskim udrugama i preuzimanje } \\
\text { studentskih poslova kako bi se, uz } \\
\text { studiranje, istovremeno kombinirale } \\
\text { različite obaveze i određivali prioriteti }\end{array}$ & $\begin{array}{l}\text { - Radionice u okviru centra za karijere o } \\
\text { postavljanju prioriteta i eliminaciji gutača } \\
\text { vremena } \\
\text { - Individualno savjetovanje studenata putem } \\
\text { centra za karijere o suvremenim metodama } \\
\text { i tehnikama upravljanja vremenom, kao što } \\
\text { su ABC tehnika ili matrica važno-hitno. }\end{array}$ \\
\hline
\end{tabular}

\section{ZAKLJUČAK}

Zapošljivost je koncept koji se u posljednjih nekoliko godina nametnuo kao alternativa sigurnosti posla za pojedince, kao glavna preokupacija institucija visokog obrazovanja koje se natječu za mjesto na globalnim ljestvicama konkurentnosti sveučilišta, ali i kao temelj na kojem se promovira nacionalna konkurentnost u globalnom okruženju. Vještine koje se uobičajeno povezuju s konceptom zapošljivosti u fokusu su ne samo diplomanata i sveučilišta, nego i poslodavaca koji očekuju od novih sudionika na tržištu rada da pri zapošljavanju već posjeduju određene transferabilne menadžerske vještine. One se mogu primijeniti na gotovo sva područja specijalizacije u visokom obrazovanju, no u području poslovne ekonomije, koje je posebno kompetitivno te vještine postaju još važnije u pokušaju da se posao nađe, zadrži te, po potrebi, zamijeni drugim poslom.

Ovo istraživanje je pokazalo da postoji značajan jaz između poslodavaca i diplomanata poslovne ekonomije u percepciji razvijenosti pojedinih konceptualnih, socijalnih i tehničkih vještina s kojima diplomanti dolaze u poslovne organizacije po završetku studija. Najveći jaz pokazuje se u području socijalnih vještina i to posebno kritičke samosvijesti, upravljanja sukobima i rada u timu te u području konceptualnih vještina odnosno kritičkom mišljenju i upravljanju vremenom. Osim kontinuiranih signala s tržišta rada oko toga koje su vještine poslodavcima potrebne u kontingentu diplomanata poslovne ekonomije, važno je osvijestiti i studente i sveučilišta o načinima na koje je moguće unaprijediti navedeni skup vještina tijekom studija. Izuzev očitih preporuka poput tijesne suradnje poslodavaca i sveučilišta, u radu su sistematizirane i smjernice za razvoj najvažnijih vještina na razini pojedinaca odnosno studenata i diplomanata $s$ jedne strane te institucija visokog obrazovanja odnosno nastavnog osoblja, uprava fakulteta i centara za karijere s druge strane. 


\title{
MANAGEMENT SKILLS AS A KEY DETERMINANT OF BUSINESS GRADUATES' EMPLOYABILITY - EMPLOYERS' AND GRADUATES' PERCEPTIONS
}

\author{
Maja Klindžić, PhD \\ University of Zagreb, Faculty of Economics \& Business \\ Trg J. F. Kennedyja 6, 10000 Zagreb, Croatia \\ Telefon: 012383 264, e-mail:mklindzic@efzg.hr \\ Kristina Pavković, MSc \\ Orbico d.o.o. \\ Ul. Kreše Golika 1, 10090, Zagreb, Croatia \\ e-mail: kristina.pavkovic@orbico.com
}

\begin{abstract}
Employability refers to a set of abilities, knowledge and skills that enable graduates to expand employment opportunities and achieve further career advancement. The main goal of the paper was to examine which skills are crucial for business graduates in search of a job, as well as to analyze the difference in perception between employers and graduates with regard to the development of selected conceptual, social and technical managerial skills. A quantitative empirical study was conducted on a sample of 30 experts mainly in the field of human resources from mostly large Croatian companies, as well as on 100 recent business graduates from the Faculty of Economics, University of Zagreb. The study revealed significant differences in the perception of the development of individual managerial skills of graduates. Compared to employers, graduates tend to overestimate almost all skills except technical knowledge and oral communication skills. The largest gap in assessment was identified in self-awareness, teamwork, conflict management and critical thinking. These results can be useful for universities in tailoring their programs based on labor market demands, as well as to business students, who can improve their skillset and maximize their employability prospects.
\end{abstract}

Keywords: employability; business graduates; social skills; technical skills; conceptual skills; technical skills 


\section{LITERATURA}

1. Alshare, K. i Sewailem, M. F. (2018). A gap analysis of business students' skills in the 21st century: A case study of Qatar. Academy of Educational Leadership Journal, 22(1), 1-22.

2. Ananiadou, K. i Claro, M. (2009). 21st Century Skills and Competences for New Millennium Learners in OECD Countries, OECD Education Working Papers, 41, OECD Publishing. doi: $10.1787 / 218525261154$

3. Andrews, J. i Higson, H. (2008). Graduate Employability, 'Soft Skills' Versus 'Hard' Business Knowledge: A European Study. Higher Education in Europe, 33(4), 411-422. doi: 10.1080/03797720802522627

4. Azevedo, A., Apfelthaler, G. i Hurst, D. (2012). Competency development in business graduates: An industry-driven approach for examining the alignment of undergraduate business education with industry requirements. The International Journal of Management Education, 10(1), 12-28. doi: 10.1016/j.ijme.2012.02.002

5. Bedwell, W. Fiore, S. i Salas, E. (2014). Developing the Future Workforce: An Approach for Integrating Interpersonal Skills into the MBA Classroom. Academy of Management Learning and Education, 13(2), 171-186. doi: 10.5465/amle.2011.0138

6. Davies, L. (2000). Why kick the "L" out of "LEarning"? The development of students' employability skills through part-time working, Education + Training. 42(8), 436-445. doi: 10.1108/00400910010379961

7. Eurich, T. (2018). Working with People Who Aren't Self-Aware, Harvard Business Review. Preuzeto s: https://hbr.org/2018/10/working-with-people-who-arent-self-aware

8. Freudenberg, B., Brimble, M. i Cameron, C. (2011). WIL and generic skill development: The development of business students' generic skills through work-integrated learning. Asia-Pacific Journal of Cooperative Education, 12(2), 79-93.

9. Goleman, D. (2010). Emocionalna inteligencija u pos/u. Zagreb: Mozaik knjiga.

10. Hodge, K. i Lear, J. (2011). Employment Skills for 21st Century Workplace: The Gap Between Faculty and Student Perceptions. Journal of Career and Technical Education, 26(2), 28-32. doi: 10.21061/JCTE.V2612.523

11. Hora, M., Benbow, R. i Smolarek, B. (2018). Re-thinking Soft Skills and Student Employability: A New Paradigm for Undergraduate Education. Change: The Magazine of Higher Learning, 50(6), 30-37. doi: 10.1080/00091383.2018.1540819

12. Horn, R. (2012). The Business Skills Handbook. London: Chartered Institute for Personal Development.

13. ILO (2017). Skills Needs Anticipation: Systems and Approaches. Geneva: International Labour Office.

14. Jackson D. (2014). Modelling graduate skill transfer from university to the workplace. Journal of Education and Work, 29(2), 199-231. doi: 10.1080/13639080.2014.907486

15. Jackson D. i Bridgstock, R. (2021). What actually works to enhance graduate employability? The relative value of curricular, co-curricular, and extra-curricular learning and paid work. Higher Education, 87(4):723-739. doi: 10.1007/s10734-020-00570-x

16. Jance, A. i Morgan, M. (2013). Critical Learning Skills For Business Students. American Journal Of Business Education, 6(1), 25-34.

17. Katz, R. (1974). Skills of an Effective Administrator. Harvard Business Review, 52(5), 90-102. 
18. Krajnović, A. Vrdoljak Raguž, I. i Bosna, J. (2019). Ishodi učenja na području upravljanja ljudskim resursima i tržišta rada na ekonomskim fakultetima i sveučilišnim odjelima u RH - kritička analiza. Poslovna izvrsnost, 13(1), 143-164. doi: 10.22598/pi-be/2019.13.1.143

19. Lisa, E., Hennelova, K. i Newman, D. (2019). Comparison between employers' and students' expectations in respect of employability skills of university graduates. International Journal of Work-Integrated Learning, 20(1), 71-82.

20. Lumley, M. i Wilkinson, J. (2014). Developing employability for business. Oxford: Oxford University Press.

21. Maslić Seršić, D. i Tomas, J. (2015). Zapošljivost kao suvremena alternativa sigurnosti posla: teorije, nalazi i preporuke u području psihologije rada. Revija za socijalnu politiku, 22(1), 95-112. doi: 10.3935/rsp.v22i1.1233

22. Mazalin, K. i Parmač Kovačić, M. (2015). Odrednice percipirane zapošljivosti studenata,. Društvena istraživanja, 24(4), 509-529. doi: 10.5559/di.24.4.03

23. Ritter, B. A., Small, E. E., Mortimer, J. W. i Doll, J. L. (2018). Designing management curriculum for workplace readiness: Developing students' soft skills. Journal of Management Education, 42(1), 80-103. doi: 10.1177/1052562917703679

24. Rotherman, A. J., Willingham, D.T (2010). "21st-Century" Skills: Not New, but a Worthy Challenge. American Educator, 34(1), 17-20.

25. Silva, E. (2009). Measuring Skills for 21st-Century Learning. The Phi Delta Kappan, 90(9), 630634. doi: 10.1177/003172170909000905

26. Succi, C. i Canovi, M. (2020). Soft skills to enhance graduate employability: comparing students and employers' perceptions. Studies in Higher Education, 45(9): 1834-1847. doi: 10.1080/03075079.2019.1585420

27. Trilling, B. i Fadel, C. (2009). 21st Century Skills: Learning for Life in Our Times. San Francisco: Jon Wiley i Sons. 